\title{
The Distinctiveness of Rural Tourism Marketing Practices: The Case Study of Bosnia and Herzegovina
}

\author{
Merima Činjarević \\ University of Sarajevo, School of Economics and Business, Bosnia and Herzegovina \\ merima.cinjarevic@efsa.unsa.ba
}

Almir Peštek

University of Sarajevo, School of Economics and Business, Bosnia and Herzegovina almir.pestek@efsa.unsa.ba

\section{Sanja Tufo}

University of Sarajevo, School of Economics and Business, Bosnia and Herzegovina sanjatufo@hotmail.com

This paper seeks to explore the distinctiveness of marketing practices of small ruralbased businesses in the context of a so-called laggard economy in South-Eastern Europe (SEE) economy: Bosnia and Herzegovina. Since this study is exploratory, we employed a qualitative methodology using the multiple-case study and semistructured interviews. We collected nine cases of small rural-based tourism business and conducted interviews with their owners. The data analysis is guided by the interpretive research paradigm. The results show that the majority of small rural-based tourism businesses are engaged in marketing activities, and they seem to have an entrepreneurial and professional attitude toward marketing actions. Moreover, the majority of small rural-based tourism business follows the so-called zoning model promoting the outstanding natural beauty and integrity to visitors. Based on the critical concepts identified during the coding process in the analysis, we extracted the following themes: product variety, the authenticity of experience, marketing capabilities, and business challenges. This study deepens our understanding of marketing activities of small tourism business in rural areas. Moreover, it provides valuable information to policy-makers to design and implement policies/programmes that foster the growth of these types of businesses.

Keywords: rural areas, marketing, tourism development, small tourism business https://doi.org/10.26493/2335-4194.12.173-184

\section{Introduction}

In recent decades, tourism activity has increased tremendously in many rural areas. Rural tourism is developing rapidly due to the growing need of the urban population to escape from every-day life and to connect with nature and traditional lifestyles (Pato \& Kastenholz, 2017). Rural tourism attracts new residents, tourists, and entrepreneurs, and, thus, it is considered to be the instrument of revitalisation and development of the life and work in rural areas (Findlay, Short, \& Stockdale, 200o). Despite the increasing importance of the rural tourism, there is a paucity of research into the marketing practices of small rural-based tourism businesses (Ateljevic \& Doorne, 2004; Pato \& Kastenholz, 2017; Siemens, 2007). More research is needed as the majority of the rural-based tourism businesses is 
small-scale and has been owned by individuals with little marketing knowledge and skills (Siemens, 2007). The lack of marketing knowledge and skills impacts the small rural-based businesses in a variety of ways, ranging from every-day operations to access to financing, and enhances the risk of business failure.

The present study contributes to the tourism literature by providing the insight into marketing practices of small rural-based tourism businesses in the context of the so-called laggard economy in the SouthEastern Europe (SEE) economy: Bosnia and Herzegovina. Notwithstanding the success in studying small rural-based tourism business in many Western European societies, researchers have paid less attention to the cases of SEE countries, which mostly have different political, economic, and social contexts that are very important for business success. Bearing this in mind and respecting the characteristics of the fragile environment of laggard SEE economies (e.g., weak policies and institutions with the lack of capacity to support small tourism businesses), this study aims to verify and expand existing theories and frameworks pertaining to marketing practices of small rural-based tourism business beyond the Western context. Due to complex administrative structures at national, regional, canton, and municipal levels, there is no integrative framework that supports systemic advancement, education and improvement of the tourism industry in Bosnia and Herzegovina (Shultz, Peštek, \& Geroulis, 2015). As a result, Bosnia and Herzegovina belongs to the lower group of countries (ranked 105 out of 140), according to the Travel \& Tourism Competitiveness Report 2019 (The World Economic Forum, 2019). Furthermore, the current policies and practices in the tourism sector are inefficient, and there is a lack of holistic tourism planning across national, regional, canton, and municipal levels (Shultz et al., 2015). These predisposing factors harm the performance of tourism businesses, particularly small businesses located in the rural area, which offers many opportunities for further investigation (though perhaps more state-oriented).

Moreover, the present study identifies critical challenges of small rural-based tourism business and, thereby, provides valuable information to policy-makers to create and implement policies/programmes that foster the growth of these types of businesses. Considering the importance of marketing in rural tourism and given the lack of studies on this topic, the main research questions of this study are: How do small rural-based tourism businesses implement marketing concept? What are the main business challenges faced by small rural-based tourism businesses?

\section{Rural Tourism and Small Tourism Businesses}

The concept of rural tourism has different meanings for different regions, regional and international organisations (e.g., UNWTO, OECD, EU) as well as individual scholars. UnWTo, for example, defines rural tourism as tourism product 'that gives visitors a personalized contact, a taste of human-environment of countryside and, as far as possible, allow them to participate in activities, tradition and lifestyles of local people' (Nair, Munikrishnan, Rajaratnam, \& King, 2014, p. 317). Similarly, Nagaraju and Chandrashekara (2014, p. 42) described rural tourism as 'any form of tourism that showcases the rural life, art, culture and heritage at rural locations.' The academic literature presents rural tourism as an umbrella concept encompassing different niche types of tourism such as agritourism, cultural tourism, nature tourism, adventure tourism, and ecotourism (e.g., Pröbstl-Haider, Melzer, \& Jiricka, 2014; Silva \& Leal, 2015). Bearing in mind that rural tourism creates positive economic, social, and environmental impacts on the local communities, it is perceived to be a crucial instrument for the revitalisation of rural areas (Silva \& Leal, 2015).

Rural tourism is a complex phenomenon characterised by following features: (1) located in rural areas; (2) functionally rural, i.e., built upon the services/activities offered by small-scale enterprises; (3) direct contact with nature and heritage; (4) tourist experience co-creation as it allows the participation in the activities, traditions and lifestyles of local people; (5) provides personalised contact; (6) rural in scale both in terms of buildings and settlements; (7) traditional in its nature, growing slowly and organically; (8) represents the complex pattern of the rural environment's, economy, history and location; (9) generates a high percentage of tourism revenue, and, thereby, 
contributed to the well-being of rural community (Roberts and Hall, 2001, p. 16).

To capture multiple facets of rural tourism, the concept of integrated rural tourism has been proposed (Saxena, Clark, Oliver, \& Ilbery, 2007). The concept of integrated rural tourism suggests that the promotion of rural tourism development ought to be based on 'strengths of local rural resources - cultural, historical, landscape-based - and the interplay between local actors and networks of exchange in order to improve the competitiveness of the rural destination' (Saxena \& Ilbery, 2010, p. 260). Bearing in mind the complex nature of rural tourism, for the purpose of this study we opted for the broad definition proposed by Komppula (2007): 'rural tourism typically refers to tourism outside densely populated areas and tourism centres' (p. 123) Given the largely rural nature of territory in Bosnia and Herzegovina and the fact the more than half of country's population is involved in agriculture and rural-based activities (Alterural, 2009), such a broad definition allows us to include almost all tourism activity within the rural areas.

Rural tourism creates an opportunity for smallscale and family-owned businesses. Although the literature offers a plethora of discussion about what constitutes a small business and what denominators ought to be employed, there is no general consensus about this issue. Typically, scholars tend to define small tourism businesses based upon the quantitative indicators such as the number of employees, room or beds (Skokic \& Morrison, 2011). In this study, we opted for a definition devised by the European Commission in 1996, which is widely accepted among scholars and practitioners. According to this definition, small businesses are firms that employ less than 50 employees. In a rural area, the tourism industry is mostly composed of such small businesses, indicating that these businesses have a pivotal role in the development of rural tourism and rural economy.

\section{Rural Tourism Marketing and Small Tourism Businesses}

Rural tourism marketing can be described as a 'platform for defining business strategies and objectives and the development of offerings that deliver unique experiences to consumers and generate profit for rural tourism destinations' (Mihailovic \& Moric, 2012, p. 267). As Saxena (2016) argues, it is a 'complex phenomenon that explains how rurality is experienced and shaped by rural tourism actors and a wide array of socio-cultural, political and material processes and practices' (Saxena, 2016, p. 4). Hence, marketing plays a significant role at every stage of the travel decisionmaking process and drives a potential visitor along the marketing funnel (i.e., attention-interest-desireaction). Although the role of rural marketing has been acknowledged, there is a paucity of research on how a marketing concept manifests itself through practices employed by small rural-based tourism businesses (Pato \& Kastenholz, 2017). The existing rural tourism marketing literature suggests that small rural-based businesses are aware of the importance of market-oriented culture (information capture, information dissemination, and the response to market) and that the adoption of market-orientated culture among them has two specific characteristics (PoloPeña, Frías-Jamilena, \& Rodrígues-Molina, 2012): (1) small rural-based businesses tend to use informal mechanisms for capturing and disseminating market information within the business; (2) small rural-based businesses are characterised by a high level of involvement with, and commitment to, the business on the part of the owner/manager (Polo-Peña et al., 2012).

Drawing on the 'practice turn' in marketing, Pato \& Kastenholz (2017) argue that marketing activities and practices differ among small rural-based businesses. By analysing the way how small rural-based businesses interpret the marketing process and the degree of their engagement across different marketing practices, Pato \& Kastenholz (2017) identified the four clusters of small rural-based business: 'passive-inward oriented businesses,' 'poorly active businesses,' 'moderately active businesses,' and 'active-market-oriented businesses.' While passive-inward oriented businesses tend to follow a resource-driven approach or insideout perspective, active-market oriented businesses successfully compete on their ability to balance the sense market trends ahead of its competitors (marketdriven approach or outside-in perspective) and their internal resources (resource-driven approach or inside- 
out perspective). Furthermore, Pato \& Kastenholz (2017) provided support for the view that marketing concept (here meaning engaging in strategic and operative marketing activities) is at the core of the success of small rural-based businesses.

The successful implementation of rural tourism marketing is not straightforward. Small rural-based tourism businesses are facing a plethora of challenges within the areas of marketing, operation, and infrastructure (Siemens, 2007). The existing literature suggests that internal factors (e.g., expertise and management skills, financial resources) and external factors (e.g., networks and environmental dynamism conditions) are also of great importance for the success of small rural-based businesses (Irvine \& Anderson, 2004). The challenges that arise from the lack of internal resources can be overcome through formal and informal networking in the tourism industry. As suggested by Saxena \& Ilbery (2008), the creation of empowering networks helps small rural-based businesses to realise the network advantage, by aggregating and creating new knowledge and building capacity. In terms of limited access to financial resources and lack of marketing expertise, it is necessary to establish public sector support as well as to design and implement adequate infrastructure policy (Ateljevic, 2009).

\section{Methodology}

Given the exploratory nature of this study, a qualitative methodology was applied to provide answers to research questions. We opted for semi-structured interviews as they offer flexibility in qualitative inquiries (Flick, 2009). More precisely, semi-structured interviews are open discussions between interviewers and interviewees about predefined themes with the possibility of adding or excluding themes from the interview scenario as interview proceeds. The interviews started with a brief explanation of the purpose of this research and the general description of the enterprise(s) owned by interviewees. The main part of interviews was organised around discussion themes related to the scope and variety of services/activities offered, marketing activities they carried out, collaboration and networking with other tourism businesses, perceived challenges facing their business, and plans.
At the end of interviews, interviewees had the opportunity to add theme(s) that they considered relevant but which had not been covered during the interview. The interviews were carried out at multiple-sites, i.e., at interviewees' businesses at a time convenient to them. A list of 64 small based-tourism businesses was obtained from Alterural, a non-profit association dedicated to the promotion and professionalisation of rural tourism in Bosnia and Herzegovina, and it served as the sampling frame for this study. The purposeful sampling was used for the selection of small rural-based tourism businesses that meet the following criteria: (1) operating in the rural area; (2) being in business at least three years; (3) having less than $50 \mathrm{em}$ ployees. Overall, nine semi-structured interviews were conducted during two months (June and July 2018), and each interview lasted from two to three hours. The interviews were transcribed first, and then the content was analysed. Each interview was coded using Arabic numbers (Table 1), and all quotes presented in the following text are linked with the code number. A brief description of selected cases helps us to understand the setting in which the small rural-based businesses operate.

Bogdan and Biklen (2003) define the qualitative data analysis as 'working with the data, organising them, breaking them into manageable units, coding them, synthesising them, and searching for patterns.' Thus, in the present study, we followed the standard format of qualitative data analysis (identifying, coding, and categorising themes). First, raw data from interviews were broken down into fragments in order to analyse, conceptualise, and develop concepts. In the second step, relationships between concepts are identified in order to group them into themes. Based on the key concepts identified during the coding process in the analysis, we extracted the following themes: product variety, the authenticity of experience, marketing capabilities, and business challenges.

\section{Results and Discussion}

In the following section, we will outline the major themes and sub-themes that emerged from the data. In the first step of our data analysis, we compared the raw data, i.e., the content of each interview and identified 
Table 1 Description of Cases and Interviewees

\begin{tabular}{|c|c|}
\hline & ode/business characteristics \\
\hline 1 & $\begin{array}{l}\text { A family-owned business established in 2011. It offers accommodation in apartments decorated in line with Bosnian } \\
\text { tradition, restaurant services, organisation of events (birthday parties, team building, business lunches), as well as } \\
\text { outdoor activities (horse riding lessons for children and adults, riding for experienced riders, traditional games like } \\
\text { bag racing and rope pulling). }\end{array}$ \\
\hline 2 & $\begin{array}{l}\text { A family-owned business established in } 2009 \text { and located in the rural area known by its beautiful nature (water } \\
\text { branches, cascades and waterfalls). It offers accommodation, food and drink services, a variety of outdoor activities. } \\
\text { Moreover, this establishment is engaged in the organic production of fruits and vegetables. }\end{array}$ \\
\hline & $\begin{array}{l}\text { A family-owned business founded in } 2015 \text {. Accommodation capacity includes } 75 \text { beds in luxury apartments and cot- } \\
\text { tages. In addition to the food and drink services, visitors have the opportunity to enjoy outdoor activities such as raft- } \\
\text { ing, hiking, biking and photo safari with jeeps. }\end{array}$ \\
\hline 4 & $\begin{array}{l}\text { A family-owned business founded in } 2016 \text { and located in the mountain area. It offers catering services, and the menu } \\
\text { is based on Bosnian specialities prepared by the wife of the owner. Currently, this establishment does not offer accom- } \\
\text { modation services. }\end{array}$ \\
\hline & $\begin{array}{l}\text { A family-owned business founded in } 2015 \text { and located in a rural area. It offers accommodation, food and drink ser- } \\
\text { vices as well as outdoor activities such as football and beach volleyball, trails, horseback riding. }\end{array}$ \\
\hline & $\begin{array}{l}\text { A family-owned business that provides accommodation in apartments with four or six beds. Also, it has a restaurant } \\
\text { with } 70 \text { indoor seats and an outdoor garden with a capacity of } 200 \text { seats. }\end{array}$ \\
\hline & $\begin{array}{l}\text { A family-owned business established in 2008. It provides accommodation in a family house located in the traditional- } \\
\text { style garden. Visitors can enjoy dishes prepared according to traditional recipes. }\end{array}$ \\
\hline & $\begin{array}{l}\text { A family-owned business that offers accommodation, food and drink services. Also, owners are growing fruits and } \\
\text { vegetables and raising livestock in smallholder (cows and sheep). }\end{array}$ \\
\hline & $\begin{array}{l}\text { A family-owned business established in 2010. It offers accommodation, food and drink services. Also, the establish- } \\
\text { ment has its own production of organic food. }\end{array}$ \\
\hline
\end{tabular}

the most frequent terms appearing across interviews. In the second step, we identified key concepts and synthesised them into sub-themes and themes (Table 2).

Personal commitment of owners. The cases studied are family-owned and family-run businesses. They are mostly founder-led enterprises characterised by entrepreneurial orientation (innovativeness, proactiveness, and propensity for taking the risk), and longterm vision. Inspiring leadership is another distinctive characteristic of the enterprises studied. Moreover, they are nourishing a sense of community - the enterprise is not an isolated entity that pursues only profit maximisation but instead, it is a member of a community that contributes to the well-being of local residents. One of the owners of enterprises stated:

The key to the success of our business is love, courage and sacrifice for what we do. The dedication of the whole family to our business throughout the day. New facilities are needed to keep tourists longer, but also to extend the season. [Case 6]

Despite the limited access to external financing sources, the enterprises studied are aware of the importance of investments. Hence, they seek to provide investments, no matter how difficult it is.

In the coming years, we plan to renovate the mill, where flour will be milled. Also, we have plans regarding the construction of a children's ski lift, the expansion of accommodation facilities and the introduction of new facilities such as the small souvenir shop. [Case 7] 
Table 2 Summary of Case Insights: Cross-Case Presentation

\begin{tabular}{ll}
\hline Emerged themes & Emerged sub-themes \\
\hline $\begin{array}{l}\text { Personal commitment } \\
\text { of owners }\end{array}$ & $\begin{array}{l}\text { Family, long-term vision, passion, love, courage, dedication, planning, risk-taking, innovative- } \\
\text { ness, development, investments }\end{array}$ \\
\hline Product variety & Accommodation, food, horse riding, hiking, rafting, trails, organic production, event organising \\
\hline Authentic experience & $\begin{array}{l}\text { Traditional food, cultural heritage, local people, uniqueness, servicescape, tourist experience } \\
\text { co-creation }\end{array}$ \\
\hline Marketing capabilities & $\begin{array}{l}\text { customer-linking capability. market-sensing capability, channel- bonding capability, internal } \\
\text { marketing capabilities (product, price, promotion and place (distribution) }\end{array}$ \\
\hline Business challenges & $\begin{array}{l}\text { Seasonality, public infrastructure, tourism infrastructure, lack of common legislative framework } \\
\text { in the area of rural tourism, limited access to financing }\end{array}$ \\
\hline
\end{tabular}

This finding is in line with the view that essential characteristics and drivers of success amongst small rural-based businesses are the owner's energy and personal commitment to goals (Zapalska \& Brozik, 2007; Getz, Carlsen, \& Morrison, 2004).

Product variety. Most enterprises offer a large variety of products, including accommodation, food and drink services, and the production and sale of organic food. Moreover, several enterprises provide opportunities for visitors to take part in outdoor leisure and adventure activities (e.g., horse riding, photo safari, fishing, hunting, biking). Product expansion allows them to create 'all-around offers' that will lead to unique tourist experiences, and consequently, enhance visitor satisfaction. Product variety strategy is partly motivated by the economic gains obtained by the provision of a flexible array of services activities. However, product variety can also be seen as a specific response of tourism enterprises to market demands. One of the enterprises in this study provides horse-riding lessons for children/adults as well as horse-riding tours for experienced riders, and he explained the strategy as follows:

We have turned our love for nature and passion for horses into a successful business. We purchased five Arabian horses and established an equestrian club where visitors can experience horse riding in a natural, safe, and familyfriendly environment. We thought people would come just to enjoy horse riding. However, it turned out that when the visitors were already here, they wanted to stay for a night or two, they wanted meals and refreshments. Driven by visitors' needs, we decided to expand our horse-riding business into accommodation and food services. Today, our guests can stay in our apartments that offer accommodation for four or six people. Also, they can choose between half board and full board meal plans in our restaurant. [Case 1]

Another enterprise is in charge of the whole value chain as it offers meals prepared by the ingredients (fruits and vegetables) coming from its own organic production. He explained the benefit of having control over the whole value chain as follows:

To be honest, we do not earn much money from growing the raspberries or from making homemade juices and jams. However, we want to serve fresh and healthy meals for our visitors. We want to offer high-quality food for our visitors. [Case 9]

Although for some enterprise's product expansion was strategically planed, some of them argued that product development is actually the response to market demands:

There is a shortage of accommodation facilities. Currently, we have fifty beds, and we cannot satisfy market demand during the pick summer 
season. Therefore, the plan is to build a bungalow with an additional number of beds as well as a new restaurant. [Case 2]

In general, all enterprises from this study are seeking ways to create overall tourist experience by providing accommodation, food, and a wide array of nature- and adventure-based activities. In addition to being able to meet market demand, they are also capable of anticipating visitors' needs and design 'allaround' offers that will create a memorable tourist experience. This finding is in line with the view that the strategy of expanding the scope and variety of product/services/activities can be seen as an effective and efficient mechanism of transforming traditional rural tourism households into professional businesses (Brandth \& Haugen, 2011; Engeset \& Heggem, 2015).

Authentic experience. Research conducted among enterprises shows that authenticity also lies at the core of these businesses. This authenticity comes in different shapes. The staged aspect of authenticity is reflected in the way that traditional dishes are prepared and presented. The importance of authenticity of gastronomic experience was discussed by one entrepreneur as follows:

We are growing organic vegetables and fruits in our garden, and we are raising livestock in smallholder (cows and sheep). We have our own authentic wooden wheel of an old watermill. My wife prepares the dishes using the traditional Bosnian recipes, and she is dressed up in traditional Bosnian clothing. We are trying to create a unique and authentic experience by preserving our cultural heritage assets. [Case 7]

Moreover, visitors have the opportunity to participate in agricultural work activities like feeding animals, picking fresh fruits or processing fruit juices and jams. The focus on tourist experience co-creation is explained by one entrepreneur, as follows:

The guests can pick fruit and vegetables from our garden and together with our cook prepare their meals. Also, they have the opportunity to engage in the production of jams and pickles. [Case 9]

The above-discussed practices are in line with the co-creation theory (Prahalad \& Ramaswamy, 2004) and the service-dominant logic (s-D logic) in marketing. According to co-creation theory and S-D logic, a tourist is an active participant rather than a passive recipient. Therefore, both service providers and tourists have to collaborate in order to provide experience value for the tourists (Lončarić, Perišić Prodan, \& Dlačić, 2017). As argued by Mathis (2013, p. 11), the tourist experience of co-creation includes the following: (1) the collaboration between the service provider and the tourist; (2) the co-production of new and improved products/services; (3) a shift away from a goods-dominant logic towards a service-dominant logic; (4) adaptability, personalisation, and uniqueness. The tourist experience co-creation can be seen as a driver of existential authenticity which in turn leads to the sense of enjoyment, escape, and experience of a 'true self' in a new place, time and culture (Kolar \& Zabkar, 2010). Bearing in mind that visitors are searching for the objective and existential authenticity in every attribute of tourism products (culture, tradition, architecture, lifestyle, entertainment, handicrafts, and cuisine), enterprises have to incorporate authentic contents into the tourism product carefully.

Marketing capabilities. Marketing literature acknowledges that a business can either compete on its ability to sense market trends ahead of its competitors (market-driven approach or outside-in perspective) or its internal resources (resource-driven approach or inside-out perspective). Furthermore, some marketing scholars argue that 'the bundle of interrelated routines that facilitate the capacity to engage in specific marketing activities and respond to the market knowledge' (Kamboj \& Rahman, 2015, p. 1041) is the central pillar of business success. Although various conceptualisations of marketing capabilities are available in the literature, they can be categorised under two broad types: the external marketing capabilities and internal marketing capabilities. The external marketing capabilities are bundles of marketing-related resources, skills and accumulated knowledge that helps a busi- 
ness to sense, understand, and respond promptly to the evolving requirements of customers and markets (Day, 2011) Examples of external marketing capabilities are market-sensing capability, customer-linking capability, or channel-bonding capability (Day, 2011; $\mathrm{Mu}, 2015)$. Internal marketing capabilities are associated with a function or practice of marketing, and these capabilities enable a firm to capitalise the full potential of market-oriented culture (Ngo \& O'Cass, 2012). Enterprises analysed in this study have achieved a certain degree of balance between outside-in and inside-out perspectives. They have the ability to anticipate the future evolution of visitor needs and detect emerging opportunities based on information collected from its business ecosystem (market-sensing capability) and the ability to create intimate relationships with the customer (customer-linking capability). Moreover, they are capable of connecting with partners and leverage the resources and capabilities through formal and informal cooperation. One enterprise explained the formal cooperation and networking as follows:

With the aim of better market positioning, the providers of services in rural tourism have formed the Eco-Pliva Association. Since many locals rent out accommodation facilities to tourists who want to feel the life in the countryside and participate in farming work, we have to cooperate. We need to exchange the knowledge and experience amongst us to keep up our businesses. [Case 2]

At the same time, enterprises have developed internal marketing capabilities, particularly customer-oriented culture. Customer orientation counts among the essential characteristics of the enterprises studied. All enterprises have emphasised their devotion to establishing and maintaining high-quality relations with their customers: 'The visitor comes as a guest and leaves like our friend. This is something for what every business in rural tourism should strive for.' [Case 3]

In terms of mid-level internal marketing capabili- ties such as the marketing mix elements, product variety is a hallmark of all enterprises. As mentioned earlier, all enterprises are trying to customise their 'allaround' offers in order to meet visitors' needs fully. Also, they are aware that they need to set competitive prices. The combination of competitive prices and high quality of services, is a recipe for success, as most of the interviewed entrepreneurs argued. Regarding the means of communication with the market, online marketing prevails over traditional marketing. Along with having their own websites, enterprises are present in social media platforms (e.g., Facebook and Instagram). Most popular distribution channels are direct contact with owners. Direct sale via Booking.com and indirect sale via travel agencies are not widely used distribution channels. One of the entrepreneurs explained its marketing channel mix as follows:

Sales and bookings are generally made directly and through the Internet, while there is no cooperation with travel agencies. Internet and brochures, as well as travel fairs, are used for the promotion. Facebook, Booking.com and Google Maps have proven to be extremely effective promotion and sales tools, especially for foreign tourists. The interest of journalists is also high, and through media coverage, they help us to enhance the awareness of rural tourism sites. [Case 5]

This finding is in line with the view that information and communication technology (IC T) helps small tourism business in a rural area to achieve better visibility and integration into economic and tourism flows (Sedmak, Planinc, Kociper, \& Planinc, 2016).

Challenges. Seasonality is perceived as a significant challenge, and it impacts the operation of small rural-based businesses in multiple ways. Since visitors generally come in the summer, the businesses have to capture as many visitors as possible during the peak summer season. Due to the limited number of rooms/beds, it is a challenging task to provide accommodation for a large number of visitors. Moreover, owners and their family members need to work long hours, resulting in unhealthy work-life balance and 
work-related stress. As with any other seasonal business, rural-based tourism business depends highly on the weather conditions. Unusually cold and rainy days during the summer implies that visitors will decide to go to other drier and warmer locations, resulting in lost sales for small rural-tourism businesses. Some businesses have realised that it is just a fact of (a business's) life, and they are responding on the seasonality by adding the weather-independent tourist activities. One example is quoted below.

All the year-around we are organising workshops for homemade products. Our visitors have the opportunity to explore how our craftsmen are making 'Bolića kolo' (weaving), village bags and woollen socks. In our facility named 'The House of Fun' visitors can learn more about the distillation of the rakija (schnapps) as well as taste our famous 'Petrovačka Šljivovica' (Peter's Plum Schnapps). [Case 6]

Access to finance is another challenge faced by studied small rural-based tourism businesses. Given that these types of business have a lower bargaining power than that of the banks and other financial institutions from whom they may seek credit, they are faced with the shortage of funds for both short-run and long-run capital needs. Furthermore, interviewed owners stated that there is a lack of public sector support through the usage of conventional public financing instruments such as grant support for small ruralbased tourism businesses or the subsidised loans are used.

Given its out-of-the-way location, the public infrastructure (water, electricity, transportation, etc.) and tourism infrastructure are not present, or it cannot sustain the increased number of visitors. Thus, additional investments in the quality of public and tourist infrastructure are needed for the further development of rural tourism. Two of the interviewed owners explained the problem of poor quality of infrastructure as follows:

The only complaints we are receiving from our visitors are related to accessibility and tourist signage. Although our location is accessible by an asphalt road from the city, more road maintenance is required, especially in the winter months. Although the tourist signage is present additional improvements are needed. [Case 1]

Our location is well connected and easily accessible. Public infrastructure and tourist signage are satisfactory. Albeit, more efforts are needed in the area of environment protection, waste management, and the reduction of pollution. [Case 4]

Another issue that hinders the success of small rural-based tourism businesses is the lack of a joint legislative framework for the management and development of rural tourism in Bosnia and Herzegovina. While the registration of rural households in Republika Srpska is regulated by the new law about catering services of the Republic of Srpska from 2017, this issue remains unresolved in Federation of Bosnia and Herzegovina. Furthermore, there is a particular gap between the induced image of Bosnia and Herzegovina as an attractive rural destination and rural tourism reality. While the marketing campaign 'Enjoy Life Bosnia \& Herzegovina' highlights the beautiful nature, mountains, rivers, lakes across Bosnia and Herzegovina, it should be noted that rural tourism remains underdeveloped. The public authorities' awareness of economic opportunities offered by developing rural tourism is rather low.

\section{Conclusion}

In terms of common traits, small rural-based tourism businesses are led by active, visionary, passionate owners who can foster, nourish and support the entrepreneurial mindset amongst their family members. Like their counterparts from the rest of the world, Bosnian and Herzegovinian small rural-based tourism businesses are also developing market-sensing and customer-linking capability. Although their investments are lower than that of their counterparts in developed economies, small rural-based tourism businesses can recognise new opportunities (sensing) and generate innovations (seizing). These findings are in 
line with the view that 'resource-picking' and 'capability-building' are substitutes for each other in achieving business success. In other words, our findings show that a shortage of internal resources (knowledge, capital) can be substituted by the company's ability to build customer-linking and market-sensing capabilities. Self-financing ss another characteristic of studied small rural-based tourism businesses. They tend to rely on self-financing from retained profit and owner's funds. In terms of external financing, they have limited access to both public and commercial financial instruments.

What specific lessons can be derived from small rural-based tourism businesses that are doing business in the economies characterised by fragility? We have identified the following lessons that can be valuable for all small tourism businesses operating in fragile business environments (also in conjunction with research questions):

- In business environments characterised by political and economic instability, there is an urgent need for businesses that are capable of sketching their own destiny in order to survive and prosper. Product variety, the authenticity of the tourist experience, customer-linking capability, marketsensing capability, and self-financing are essential building blocks of a successful small rural-based tourism business.

- If it seems that business environment does not provide an option for sustainable growth (domestic tourists) tourism businesses should be able to recognise new opportunities on regional/global markets (market sensing) and create services/activities based on these opportunities (market seizing). Also, if one is a small player in the tourism industry, one needs to create formal and informal networks with other small tourism businesses. Thus, the saying 'If you do not like how the table is set, turn over the table' vividly explains the basic rule of the business game played by studied small rural-based tourism businesses.

The findings of the present study offer some insights for policy-makers. Although the studied small rural-tourism businesses have put enormous effort into designing and providing services/activities to meet and even exceed visitors' expectations, it seems that the owners of these businesses are making marketing decisions and solutions based on the trial-anderror method. Their marketing strategies are reactive not proactive: they respond to changes in the market instead of anticipating them. Their actions regarding marketing are mostly based on the trialerror method than sound knowledge about strategic marketing (Segmentation, Targeting and Positioning). Thus, local governments and tourism organisations ought to reinforce their know-how by designing and implementing tailored training programmes for small rural-based tourism businesses. Furthermore, local and entity governments should strategically plan the investments in public and tourism infrastructure, thereby providing necessary conditions for the lucrative operation of small rural-based tourism businesses. Moreover, issues related to the legislative framework of rural tourism (i.e., the registration of rural households) need to be solved in both entities.

Due to its exploratory nature, this study has limitations. It examined marketing practices and challenges solely from the perspective of small rural-based tourism businesses in one country. Therefore, it would be valuable to consider how the marketing practices of small rural-based tourism businesses are perceived by visitors and/or how various levels of government can support the growth of these types of businesses.

\section{References}

Ateljevic, J. (2009). Tourism entrepreneurship and regional development: Example from New Zealand. International Journal of Entrepreneurial Behaviour and Research, 15(3), 282-308.

Ateljevic, J., \& Doorne, S. (2004). Diseconomies of scale: A study of development constraints in small tourism firms in central New Zealand. Tourism and Hospitality Research, 5(1), 5-24.

Bogdan, R. C., \& Biklen, S. K. (2003). Qualitative research for education: An introduction to theory and methods (4th ed.). Boston, mA: Pearson Education.

Brandth, B., \& Haugen, M. S. (2011). Farm diversification into tourism: Implications for social identity? Journal of Rural Studies, 27(1), 35-44.

Day, G. S. (2011). Closing the marketing capabilities gap. Journal of Marketing, 75(4), 183-195. 
Engeset, A. B., \& Heggem, R. (2015). Strategies in Norwegian farm tourism: Product development, challenges, and solutions. Scandinavian Journal of Hospitality and Tourism, 15(1/2), 122-137.

Findlay, A. M, Short D., \& Stockdale, A. (200o). The labourmarket impact of migration to rural areas. Applied Geography, 20(4), 333-348.

Flick, U. (2009). An introduction to qualitative research. London, England: Sage.

Getz, D., Carlsen, J., \& Morrison, A. (2004). The family business in tourism and hospitality. Wallingford, England: CABI.

Irvine, W., \& Anderson, A. (2004). Small tourist firms in rural areas: Agility, vulnerability and survival in the face of crisis. International Journal of Entrepreneurial Behavior \& Research, 10(4), 229-246.

Kamboj, S., \& Rahman, Z. (2015). Marketing capabilities and firm performance: Literate review and future research agenda. International Journal of Productivity and Performance Management, 64(8), 1041-1067.

Kolar, T., \& Zabkar, V. (2010). A consumer-based model of authenticity: An oxymoron or the foundation of cultural heritage marketing? Tourism Management, 31(5), 652664.

Komppula, R. (2007). Developing rural tourism in Finland through entrepreneurship. In R. Thomas \& M. Augustyn (Eds.), Tourism in the new Europe: Perspectives on SME policies and practices (pp. 123-133). Oxford, England: Elsevier.

Lončarić, D., Perišić Prodan, M., \& Dlačić, J. (2017). Cocreating tourist experiences to enhance customer loyalty and travel satisfaction. In S. Marković \& J. D. Smolčić (Eds.), Proceedings of 4 th International Scientific Conference TOSEE - Tourism in Southern and Eastern Europe 2017 (Vol. 4, pp. 321-334). Opatija, Croatia: University of Rijeka.

Mathis, E. (2013). The effects of co-creation and satisfaction on subjective well-being (Unpublished master thesis). Virginia Polytechnic Institut, Blacksburg, vA.

Mihailovic, B., \& Moric I. (2012). The role of marketing philosophy in rural tourism development. Tourism and Hospitality Management, 18(2), 267-279.

$\mathrm{Mu}$, J. (2015). Marketing capability, organizational adaptation and new product development performance. Industrial Marketing Management, 49(1), 151-166.

Nagaraju, L. G., \& Chandrashekara, B. (2014). Rural tourism and rural development in India. International Journal of Interdisciplinary and Multidisciplinary Studies, 1(6), 4248.
Nair, V., Munikrishnan, U. T., Rajaratnam, S. D., \& King, N. (2014). Redefining rural tourism in Malaysia. Asia Pacific Journal of Tourism Research, 20(3), 314-337.

Ngo, L. V., \& O'Cass, A. (2012). Performance implications of market orientation, marketing resources, and marketing capabilities. Journal of Marketing Management, 28(1/2), 173-187.

Pato, L., \& Kastenholz, E. (2017). Marketing of rural tourism: A study based on rural tourism lodgings in Portugal. Journal of Place Management and Development, 10(2), 121-139.

Polo-Peña, A. I., Frías-Jamilena, D. M., \& Rodrígues-Molina, M. Á. (2012). Marketing practices in the Spanish rural tourism sector and their contribution to business outcome. Entrepreneurship \& Regional Development, 24(7/8), 503-521.

Prahalad, C. K., \& Ramaswamy, V. (2004). Co-creating unique value with customers. Strategy \& Leadership, 32(3), 4-9.

Pröbstl-Haider, U., Melzer, V., \& Jiricka, A. (2014). Rural tourism opportunities, strategies and requirements for destination leadership in peripheral areas. Tourism $R e$ view, 69(3), 216-228.

Roberts, L., \& D. Hall. (2001). Rural tourism and recreation: Principles to practice. Wallingford, England: CA B I.

Saxena, G. (2016). Marketing rural tourism: Experience and enterprise. Cheltenham, England: Edward Elgar.

Saxena, G., Clark, G., Oliver, T., \& Ilbery, B. (2007). Conceptualizing integrated rural tourism. Tourism Geographies, 9(4), 347-370.

Saxena, G., \& Ilbery, B. (2008). Integrated rural tourism: A broader case study. Annals of Tourism Research, 35(1), 233-254.

Saxena, G., \& Ilbery, B. (2010). Developing integrated rural tourism: Actor practices in the English/Welsh border. Journal of Rural Studies, 26(3), 260-271.

Sedmak, G., Planinc, T., Kociper, T., \& Planinc, S. (2016). Managers' perceptions of the role of ICT in rural tourism firms efficiency: The case of Slovenia. Tourism, 64(3), 339-345.

Shultz, C. J., Peštek, A., \& Geroulis, E. (2015). Challenges and opportunities for development of sustainable tourism in Bosnia and Herzegovina. In Proceedings of the 4oth Annual Macromarketing Conference (pp. 697-698). Chicago, IL: Loyola Univeristy.

Siemens, L. (2007). Challenges faced by rural/remote tourism businesses on Vancouver Island: an exploratory study. Journal of Enterprising Communities: People and Places in the Global Economy, 1(4), 308-320. 
Silva, L., \& Leal, J. (2015). Rural tourism and national identity building in contemporary Europe: Evidence from Portugal. Journal of Rural Studies, 38(2015), 109-119.

Skokic, V, \& Morrison. A. (2011). Conceptions of tourism lifestyle entrepreneurship: Transition economy context. Tourism Planning \& Development, 8(2), 157-169.

The World Economic Forum. (2019). The travel \& tourism competitiveness report 2019. Geneva, Switzerland: Author.
Zapalska, A., \& Brozik, D. (2007). Managing family businesses in the tourism and hospitality tndustry: The transitional economy of Poland. Zbornik radova Ekonomskog fakulteta u Rijeci, 25(1), 141-165.

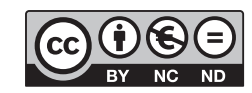

This paper is published under the terms of the Attribution- NonCommercial-NoDerivatives 4.0 International (CC B Y-NC-ND 4.0) License. 